\title{
HUBUNGAN PENGETAHUAN DAN SIKAP PERAWAT DENGAN PELAKSANAAN DISCHARGE PLANNING PASIEN DI RSUD PROF. DR. W.Z. JOHANNES KUPANG
}

\author{
${ }^{1}$ Bonevasius Bhute, 'Ina Debora Ratu Ludji,. and ${ }^{3}$ Pius Weraman. \\ ${ }^{1}$ Rumah Sakit Umum Daerah, WZ Johanes Kupang \\ 2Prodi Kebidanan, Poltekes Kemenkes Kupang \\ 3Prodi IKM, FKM-Universitas Nusa Cendana
}

\begin{abstract}
ABSTRAK
$D$ ischarge planning merupakan bagian penting dari program keperawatan klien yang dimulai segera setelah klien masuk rumah sakit dengan menggambarkan usaha kerja sama antara tim kesehatan, keluarga, klien, dan orang yang penting bagi klien. Perawat memberikan informasi melalui pendidikan kesehatan kepada klien yang membutuhkan perawatan diri untuk memastikan kontinuitas pelayanan dari rumah sakit ke rumah atau komunitas. Pelaksanaan discharge planning sampai saat ini belum optimal dilakukan oleh perawat dan berdampak terhadap menurunnya motivasi kesembuhan pasien, memanjangnya LOS (length of stay), meningkatnya angka kekambuhan dan beban pembiayaan pasien terhadap rumah sakit. Pengetahuan, dan sikap perawat yang baik sangat menentukan keberhasilan pelaksanaan discharge planning pasien secara tepat dan optimal. Penelitian ini bertujuan menganalisis hubungan pengetahuan perawat dengan pelaksanaan discharge planning di RSUD Prof. Dr. W.Z. Johannes Kupang, dan menganalisis hubungan sikap perawat dengan pelaksanaan discharge planning di RSUD Prof. Dr. W.Z. Johannes Kupang. Desain penelitian deskriptif korelasi dengan pendekatan cross sectional dimana peneliti ingin mengkaji hubungan determinan perilaku perawat dalam manajemen asuhan keperawatan tim dengan pelaksanaan discharge planning di RSUD Prof. Dr. W.Z. Johannes Kupang. Sampel penelitian adalah ketua tim perawat di Instalasi Rawat Inap RSUD Prof. Dr. W.Z. Johannes Kupang sebanyak 40 orang dengan menggunakan teknik pengambilan total sampling. Analisis data menggunakan korelasi Spearman rank pada analisis bivariat.Hasil penelitian menunjukkan pengetahuan perawat berada pada kategori baik dan ada hubungan yang lemah antara pengetahuan perawat dengan pelaksanaan discharge planning dengan nilai $\mathrm{p}=0,057$ dan koefisien korelasi 0,303. Sikap perawat pada kategori cukup baik dan ada hubungan yang kuat antara sikap perawat dengan pelaksanaan discharge planning dengan nilai $\mathrm{p}=0,000$ dan koefisien korelasi 0,612 . Perawat mempunyai pengetahuan yang baik dan sikap yang cukup baik tentang discharge planning, sedangkan pelaksanaan discharge planning belum optimal dilaksanakan. Terdapat hubungan yang lemah antara pengetahuan dan pelaksanaan discharge planning, dan ada hubungan yang kuat antara sikap dengan pelaksanaan discharge planning. Hasil penelitian ini merekomendasikan perlunya pendidikan formal, pelatihan discharge planning bagi perawat untuk meningkatkan kompetensi perawat dalam melaksanakan discharge planning dan monitoring evaluasi secara teratur dan berkesinambungan dari manajer keperawatan dan manajer rumah sakit.
\end{abstract}

Kata kunci: Pengetahuan, sikap, discharge planning 


\title{
RELATIONSHIP KNOWLEDGE AND ATTITUDE NURSING WITH IMPLEMENTATION OF DISCHARGE PLANNING PATIENTS IN PROF. DR. W.Z. JOHANNES KUPANG
}

\author{
${ }^{1}$ Bonevasius Bhute, ${ }^{2}$ Dr. Ina Debora Ratu Ludji, M.Kes. ${ }^{3}$ Dr. Pius Weraman, M.Kes. \\ ${ }^{1}$ Regional Public Hospital, WZ Johanes Kupang \\ 2Prodi Kebidanan, Poltekes Kemenkes Kupang \\ 3Prodi IKM, FKM-Universitas Nusa Cendana
}

\begin{abstract}
Discharge planning is an important part of the client's nursing program that begins as soon as the client is admitted to the hospital by describing the cooperative effort between the health team, the family, the client, and the person important to the client. The nurse provides information through health education to clients who need self-care to ensure continuity of service from hospital to home or community. Implementation of the discharge planning until now has not been optimally performed by nurses and has an impact on the decrease of patient's healing motivation, the lengthening of LOS (length of stay), the increasing of recurrence rate and the burden of patient's financing to the hospital. Knowledge, and good nurse attitude determine the successful implementation of patient discharge planning appropriately and optimally. This study aims to analyze the relationship of knowledge nurses with the implementation of discharge planning in RSUD Prof. Dr. W.Z. Johannes Kupang, and analyzing the relationship of nurse attitude with the implementation of discharge planning in RSUD Prof. Dr. W.Z. JohannesKupang. Descriptive correlation research design with cross sectional approach where the researcher wanted to study the relationship of determinant of nurse behavior in management of nursing care team with discharge planning implementation in RSUD Prof. Dr. W.Z. Johannes Kupang. The sample of the research is the head of the team of nurses at the Inpatient Installation of RSUD Prof. Dr. W.Z. Johannes Kupang counted 40 people using total sampling technique. Data analysis using Spearman rank correlation on bivariate analysis. The results showed that nurse knowledge was in good category and there was a weak relationship between nurse knowledge with discharge planning implementation with $\mathrm{p}$ value $=0,057$ and correlation coefficient 0,303 . The nurse's attitude on the category is quite good and there is a strong relationship between nurse attitude with discharge planning implementation with $\mathrm{p}$ value $=0,000$ and correlation coefficient 0,612. Nurses have good knowledge and a good attitude about discharge planning, while the implementation of discharge planning has not been optimally implemented. There is a weak relationship between knowledge and discharge planning, and there is a strong relationship between attitude and discharge planning. The results of this study recommend the need for formal education, discharge planning training for nurses to improve nurse competence in implementing discharge planning and monitoring regularly and continuously evaluation of nursing managers and hospital managers.
\end{abstract}

Keywords : Knowledge, attitude, discharge planning 


\section{PENDAHULUAN}

Kontinuitas pelayanan pasien akan terjamin dengan baik sangat dibutuhkan pelaksanaan discharge planning yang terprogram secara tepat dan adekuat. Discharge planning merupakan suatu proses yang sistematis untuk menilai, menyiapkan, dan melakukan koordinasi dengan fasilitas kesehatan yang ada atau yang telah ditentukan serta bekerjasama dengan pelayanan sosial yang ada di komunitas, sebelum dan sesudah pasien pindah/pulang dari institusi pelayanan kesehatan (Carpenito, 2002, dalam Hariyati, 2008). Discharge Planning yang efektif seharusnya mencakup pengkajian berkelanjutan untuk mendapatkan informasi yang komprehensif tentang kebutuhan pasien yang berubah-ubah, pernyataan diagnosa keperawatan, perencanaan untuk memastikan kebutuhan pasien sesuai dengan apa yang dilakukan oleh pemberi layanan kesehatan (Kozier, 2004 dalam Octaviani, 2016).

Discharge planning yang belum optimal menimbulkan dampak bagi pasien yaitu meningkatnya angka rawatan ulang dan pada akhirnya pasien akan menanggung pembiayaan untuk biaya rawat inap dan juga rumah sakit dimana lambat laun akan ditinggalkan oleh pelanggan (Hariyati, 2014). Archie dan Baron (2006), menyebutkan proses discharge planning yang tidak memenuhi standar di 38 rumah sakit di Amerika Serikat menyebabkan pasien harus kembali ke rumah sakit untuk menjalani perawatan. Hasil penelitian di Inggris yang dilakukan oleh Shepperd, et al. (2010), bahwa pasien yang diberikan intervensi discharge planning terjadi peningkatan kepuasan dibandingkan dengan pasien yang menerima pemulangan secara rutin. Beberapa penelitian yang dilakukan yang menggambarkan pelaksanaan discharge planning yakni penelitian di tiga rumah sakit di kota Bukit Tinggi tahun 2010 didapatkan bahwa terdapat 10\% pasien penyakit jantung koroner mengalami rawatan ulang. Diperkirakan bahwa salah satu penyebab terjadinya rawatan ulang yaitu kemungkinan ketidaksiapan pasien pulang ke rumah dengan rata-rata rentang pasien yang mengalami rawatan ulang dari rawatan sebelumnya tiga sampai enam bulan (Wahyuni, Nurachmah \& Gayatri, 2012). Penelitian Purnamasari dan Ropyanto (2012), menunjukan bahwa discharge planning pasien di RSUD Tugurejo Semarang belum optimal dilaksanakan dimana terdapat 46,6\% kategori cukup, 13,6\% kategori kurang dan 39,8\% ketegori baik dalam melaksanakan discharge planning. Penelitian oleh Octaviani dan Dermawan (2016), menunjukan bahwa pengetahuan perawat tentang discharge planning berada pada kategori 
cukup $65 \%$ dan pelaksanaan discharge planning 64,6\% dan tidak ada hubungan antara pengetahuan dengan pelaksanaan discharge planning di ruang rawat inap RS Tk. II Dustira Cimahi. Penelitian oleh Khalidawati (2016) di RSU dr. Zaninoel Abidin Banda Aceh diperoleh hasil perilaku perawat dalam pelaksanaan discharge planning dengan kategori baik $66,49 \%$ dimana pengetahuan $54,97 \%$, sikap perawat $67,02 \%$ dan tindakan perawat $67,02 \%$.

Hasil observasi yang dilakukan pada survey awal di RSUD Prof. Dr. W.Z.Johannes Kupang diperoleh bahwa pelaksanaan discharge planning hanya dilakukan oleh perawat sedangkan professional pemberi asuhan lainnya (dokter, apoteker dan ahli gizi) belum terlibat aktif dalam pelaksanaannya. Perawat dalam pelaksanaan discharge planning baru sebatas melakukan implementasi tindakan keperawatan yang berhubungan dengan discharge planning tanpa melalui tahapan proses keperawatan yang mulai dari pengkajian sampai evaluasi. Berdasarkan hasil wawancara dengan kepala ruangan dan ketua tim pada empat ruangan rawat inap bahwa discharge planning merupakan hal yang baru di RSUD Prof. Dr. W.Z. Johannes Kupang pada tahun 2016 dan belum sepenuhnya dipahami baik perawat maupun profesional pemberi asuhan lainnya, akibatnya kesinambungan dalam pelayanan pasien belum dilaksanakan sepenuhnya.

Pelaksanaan strategi yang dilakukan rumah sakit untuk meningkatkan kompetensi perawat dalam pelaksanaan discharge planning adalah dengan penerapan manajemen asuhan keperawatan secara tepat dan efektif karena dengan manajemen asuhan keperawatan dapat memberikan asuhan keperawatan yang professional kepada pasien/keluarganya melalui penyelesaian pekerjaan oleh perawat. Unsur-unsur dikelola oleh seorang manajer yang meliputi orang, metode, materi, anggaran, waktu dan pemasaran (Kusnanto, 2006). Manajer keperawatan memerlukan pengetahuan yang memadai dan sikap yang positip sehingga terbentuknya tindakan yang terbaik dalam pelaksanaan manajemen keperawatan.

\section{BAHAN DAN METODE}

Desain penelitian ini adalah deskriptif korelasi dengan rancangan cross sectional untuk menganalisis hubungan antara pengetahuan dan sikap perawat dengan pelaksanaan discharge planning. Sampel dalam penelitian ini adalah ketua tim perawat di ruang rawat inap RSUD Prof. Dr. W.Z. Johannes Kupang. Sampel diambil dengan teknik total sampling dan besarnya sampel dalam penelitian ini sebanyak 40 orang. Pelaksanaan pengambilan data 
penelitian dilakukan tanggal 03 - 24 Mei 2017 di Ruang Rawat Inap RSUD Prof. Dr. W.Z.Johannes Kupang.

Data dikumpulkan menggunakan kuesioner untuk pengetahuan dan sikap perawat, dan panduan observasi discharge planning untuk pelaksanaan discharge planning. Kuesioner pengetahuan dan sikap perawat dibuat peneliti berdasarkan konsep teori manajemen keperawatan tim dan discharge planning. Panduan observasi pelaksanaan discharge planning mengacu pada pedoman observasi pelaksanaan discharge planning National Council of Social Services (NCSS) dan Rofi'i (2011). Uji validitas dilakukan pada 10 orang perawat di ruangan ICU, ICCU, dan Ruang Maya C RSUD Prof. Dr. W.Z.Johannes Kupang dan Pernyataan yang dinyatakan valid jika $r$ hitung $\geq \mathrm{r}$ tabel $(0,632)$. Hasil uji validitas menggunakan Pearson product moment didapatkan variabel pengetahuan perawat nilai validitas antara 0,907 - 0,658, dan variabel sikap perawat diperoleh hasil antara 0,952 0,660. Hasil uji reliabilitas instrumen dengan alpha cronbach didapatkan variabel pengetahuan diperoleh nilai 0,962 , dan variabel sikap perawat diperoleh hasil 0,939. Penelitian ini mempertimbangkan prinsip dasar etik penelitian keperawatan yaitu menghormati harkat dan martabat manusia, menghormati privasi dan kerahasiaan subjek, menghormati keadilan dan inklusivitas, serta memperhitungkan manfaat dan kerugian yang ditimbulkan.

\section{HASIL PENELITIAN}

1. Gambaran karakteristik responden

Hasil analisis menunjukkan bahwa sebagian besar jenis kelamin responden perempuan 39 orang $(97,7 \%)$, berpendidikan D3 Keperawatan 30 orang $(75 \%)$ dan Ners hanya 6 orang (15\%), status perkawinan menikah 35 orang (87,5\%), dan bekerja dengan status PNS 39 orang $(97,5)$.

Tabel 1 Distribusi Responden berdasarkan Jenis Kelamin, Tingkat Pendidikan, Status Perkawinan Dan Kepegawaian di RSUD Prof. Dr. W.Z.Johannes Kupang

\begin{tabular}{ccc}
\hline \multicolumn{1}{c}{ Variabel } & Jumlah & Presentasi (\%) \\
\hline Jenis kelamin & 39 & 97,5 \\
a. Perempuan & 1 & 2,5 \\
b. Laki-laki & & \\
Tingkat pendidikan & 30 & 75 \\
a. D3 & 4 & 10 \\
b. D4 &
\end{tabular}


c. Ners

Status perkawinan

a. Belum menikah

b. Menikah

Status pekerjaan
6

5

35
15

12,5

87,5

2,5

97,5

Selanjutnya pada Tabel 2 terlihat bahwa rata-rata umur responden 39 tahun dengan umur termuda 29 tahun, tertua 53 tahun, dan interval 95\% CI rata-rata umur 36,96-40,99 tahun. Rata-rata masa kerja responden 15 tahun dengan masa kerja minimal 7 tahun, maksimal 23 tahun, dan 95\% (CI) rata-rata masa kerja responden adalah 13,43-16,42 tahun.

Tabel 2 Distribusi rata-rata umur dan masa kerja responden di RSUD Prof. Dr. W.Z.Johannes Kupang

\begin{tabular}{lccc}
\hline \multicolumn{1}{c}{ Variabel } & Median & Min-Max & $95 \%$ CI \\
\hline Umur & 39 & $29-53$ & $36,96-40,99$ \\
Masa kerja & 15 & $7-23$ & $13,43-16,42$ \\
\hline
\end{tabular}

Rata-rata umur responden 39 tahun dengan umur termuda 29 tahun, tertua 53 tahun, dan interval 95\% CI rata-rata umur 36,96-40,99 tahun. Rata-rata masa kerja responden 15 tahun dengan masa kerja minimal 7 tahun, maksimal 23 tahun, dan 95\% (CI) rata-rata masa kerja responden adalah 13,43-16,42 tahun.

2. Gambaran pengetahuan, sikap perawat dan pelaksanaan discharge planning

Hasil analisis menunjukkan bahwa pengetahuan responden baik 26 orang (65\%), cukup 11 orang (27,5\%), dan kurang 3 orang (7,5\%). Sikap responden cukup baik 31 orang $(77,5 \%)$ dan baik 9 orang $(22,5 \%)$. Pelaksanaan discharge planning pada pasien dengan kategori kurang baik 34 orang (85\%) dan baik 6 orang (15\%).

Tabel 3 Distribusi frekuensi pengetahuan, sikap perawat dan pelaksanaan discharge planning di RSUD Prof. Dr. W.Z.Johannes Kupang

\begin{tabular}{rcc}
\hline \multicolumn{1}{c}{ Variabel } & Jumlah & Persentase (\%) \\
\hline Pengetahuan & & \\
a. Kurang & 3 & 7,5 \\
b. Cukup & 11 & 27,5 \\
c. Baik & 26 & 65 \\
Sikap & & \\
a. Cukup & 31 & 77,5 \\
b. Baik & 9 & 22,5 \\
\hline
\end{tabular}


Pelaksanaan discharge planning
a. Kurang
b. Baik
6
15

3. Hubungan pengetahuan dan sikap perawat dengan pelaksanaan discharge planning

Hasil analisis (Tabel 4) menunjukkan bahwa responden dengan pengetahuan baik yang melaksanakan discharge planning dengan baik sebanyak 6 orang $(23,1 \%)$, sedangkan pengetahuan baik yang tidak melaksanakan discharge planning dengan baik sebanyak 20 orang $(76,9 \%)$. Responden dengan pengetahuan cukup dan kurang tidak melaksanakan discharge planning dengan baik. Hasil uji analisis korelasi spearman menunjukan nilai $p=$ $0,057>\alpha=0,05$ dengan koefisien korelasi sebesar 0,303, menandakan bahwa ada hubungan yang lemah antara pengetahuan perawat dengan pelaksanaan discharge planning.

Tabel 4 Analisis hubungan perilaku perawat dalam manajemen asuhan keperawatan tim dengan pelaksanaan discharge planning di RSUD Prof. Dr. W.Z.Johannes Kupang

\begin{tabular}{|c|c|c|c|c|c|c|c|c|c|}
\hline \multirow{2}{*}{\multicolumn{2}{|c|}{ Perilaku Perawat }} & \multirow{2}{*}{\multicolumn{4}{|c|}{$\begin{array}{c}\text { Pelaksanaan Discharge } \\
\text { Planning }\end{array}$}} & \multirow{2}{*}{\multicolumn{2}{|c|}{ Total }} & \multirow{4}{*}{$\begin{array}{l}\text { Koefisien } \\
\text { korelasi } \\
\text { Spearman }\end{array}$} & \multirow{5}{*}{$p$} \\
\hline & & & & & & & & & \\
\hline & & \multicolumn{2}{|c|}{ Kurang } & \multicolumn{2}{|c|}{ Baik } & & & & \\
\hline & & $\mathrm{N}$ & $\%$ & $\mathrm{~N}$ & $\%$ & $\mathrm{~N}$ & $\%$ & & \\
\hline & Kurang & 3 & 100 & 0 & 0 & 3 & 100 & & \\
\hline \multirow[t]{2}{*}{ Pengetahuan } & Cukup & 11 & 100 & 0 & 0 & 11 & 100 & 0,303 & 0,057 \\
\hline & Baik & 20 & 76,9 & 6 & 23,1 & 26 & 100 & & \\
\hline \multirow[t]{2}{*}{ Sikap } & Cukup & 30 & 96,8 & 1 & 3,2 & 31 & 100 & 0,612 & 0,000 \\
\hline & Baik & 4 & 44,4 & 5 & 55,6 & 9 & 100 & & \\
\hline
\end{tabular}

Responden dengan sikap baik yang melaksanakan discharge planning dengan baik sebanyak 5 orang $(55,6 \%)$, sedangkan sikap baik yang tidak melaksanakan discharge planning dengan baik sebanyak 4 orang $(44,4 \%)$. Responden dengan sikap cukup baik yang melaksanakan discharge planning dengan baik sebanyak 1 orang $(3,2 \%)$, sedangkan responden yang memiliki sikap cukup baik dan kurang dalam pelaksanaan discharge planning sebanyak 30 orang (96,8\%). Hasil uji analisis korelasi menunjukan nilai $p=0,000<\alpha=0,05$ dengan koefisien korelasi sebesar 0,612, menandakan bahwa ada hubungan yang kuat antara sikap perawat dengan pelaksanaan discharge planning. 


\section{PEMBAHASAN}

1. Karakteristik responden

Jenis kelamin responden sebagian besar adalah perempuan (97,5\%). Robbins dan Judge (2013), menyatakan bahwa tidak ada perbedaan antara laki-laki dan perempuan dalam kinerja, kemampuan memecahkan masalah, keterampilan analisis, motivasi dan dorongan kompetitif. Peneliti berpendapat bahwa pekerjaan perawat masih banyak diminati oleh perempuan dibandingkan laki-laki karena keperawatan masih diidentikan dengan pekerjaan yang cocok dan sesuai dengan sifat perempuan yang lebih sabar, lemah lembut dan peduli.

Tingkat pendidikan responden sebagian besar D3 keperawatan yakni sebesar 75\% dibandingkan dengan yang berpendidikan Ners hanya 15\%. Peneliti berpendapat bahwa perencanaan pengembangan pola ketenagaan perawat di rumah sakit tidak terencana dan terpola secara sistematis dan berkesinambungan. Semakin tinggi pendidikan akan semakin kritis, logis dan sistematis dalam berpikir sehingga meningkatkan kualitas kerjanya. Sejalan dengan pendapat Siagian (2006) yang mengemukakan bahwa semakin tinggi pendidikan seseorang, maka besar keinginan untuk memanfaatkan pengetahuan dan ketrampilan yang dimilikinya.

Analisis status kepegawaian dan perkawinan responden sebagian besar PNS dan sudah menikah. Status kepegawaian dan perkawinan tidak mempunyai pengaruh langsung terhadap pelaksanaan discharge planning dimana peneliti berpendapat bahwa RSUD Prof. Dr. W.Z. Johannes kupang merupakan rumah sakit milik Pemerintah Propinsi NTT, ketenagaan perawat yang bekerja diatur sesuai dengan regulasi pemerintah baik dalam hal status kepegawaian maupun jenjang karier dan jabatan.

Hasil analisis menunjukan bahwa rata-rata umur responden berada pada umur produktif yaitu 39 tahun. Robbins dan Judge (2013), menyatakan bahwa produktivitas seseorang dipengaruhi oleh umur. Umur berkaitan dengan kedewasaan psikologis, dengan bertambahnya umur akan semakin bijaksana dalam mengambil keputusan serta memiliki kemampuan analisis yang baik terhadap fenomena atau permasalahan yang dihadapi (Siagian, 2009). Menurut Gibson (1996), menyatakan bahwa umur dapat mempengaruhi kinerja dimana pengembangan karir terjadi pada usia produktif, selain itu 
ketrampilan seseorang terutama dalam hal kecepatan, kecekatan, kekuatan dan koordinasi dihubungkan dengan bertambahnya waktu.

Masa kerja responden rata-rata 15 tahun kerja. Menurut Dessler (1997), menyatakan bahwa rentang 5 tahun dianggap sudah berpengalaman dalam bekerja. Perawat yang memiliki masa kerja yang semakin lama di pelayanan klinis akan semakin baik penampilan klinisnya (Swanburg, 2002). Masa kerja yang lebih lama seharusnya mempunyai efek terhadap perilaku dan kinerjanya dalam melaksanakan asuhan keperawatan.

2. Gambaran pengetahuan, sikap perawat dan pelaksanaan discharge planning

Analisis pengetahuan perawat menunjukan bahwa sebagian besar perawat mempunyai pengetahuan yang memadai tentang discharge planning. Perawat sudah memahami tentang elemen discharge planning, pelaksanaan discharge planning yang baik dapat meningkatkan penerimaan profesi perawat oleh masyarakat, pelaksanaan discharge planning harus dilakukan segera setelah pasien masuk rumah sakit dalam waktu kurang dari 48 jam dengan melakukan pendekatan proses keperawatan mulai dari pengkajian, diagnosa keperawatan, intervensi, impelementasi dan evaluasi, dan pelaksanaan discharge planning harus melibatkan semua profesinal pemberi asuhan. Perawat juga masih mempunyai pemahaman yang kurang baik terutama pada tujuan dilaksanakan discharge planning, penerima discharge planning, tanggung jawab dan koordinasi pelaksanaan discharge planning, dan penatalaksanaan discharge planning pada hari pemulangan. Pemahaman perawat tentang konsep discharge planning ini bervariasi disebabkan karena penerapan pelaksanaan discharge planning baru dilaksanakan dalam 1 tahun ini dan kurang sosialisai ke seluruh perawat sehingga pemahamannya belum semuanya memahaminya.

Analisis sikap perawat dalam pelaksanaan discharge planning menunjukan bahwa sebagian besar perawat menunjukan perilaku cukup baik. Perawat sudah menunjukan perilaku yang baik dalam hal membuat perencanaan berdasarkan tugas dan kewenangan yang didelegasikan kepadanya dengan penuh rasa tanggung jawab, mengetahui kondisi setiap pasien yang dibawah asuhannya dan dapat menilai tingkat ketergantungan serta kebutuhannya, dan sudah melakukan penugasan kepada perawat pelaksana sesuai kompetensi perawat dalam melaksanakan asuhan keperawatan. Perawat belum 
menunjukan sikap yang optimal terutama dalam komunikasi efektif, belum optimal dalam memfasilitasi peran kolaborasi dan fasilitotor, supervisi yang kurang, penggunanaan waktu yang tidak efektif, evalusi belum dilakukan secara jujur dan objektiv, dan belum menunjukan role model yang baik. Sikap perawat dalam kategori cukup baik dan belum dikatakan baik karena sistem monitoring dan evaluasi tidak dilakukan secara teratur dan berkesinambungan serta supervisi manajer keperawatan dan rumah sakit yang kurang mengakibatkan kurangnya pengawasan dan resistensinya pola kebiasaan menjadi permanen.

Pelaksanaan discharge planning pasien masih belum optimal, sebagian besar perawat belum melakukan discharge planning dengan baik. Perawat baru melakukan discharge planning pada tahap pengkajian sedangkan pelaksanaan discharge planning pada tahap diagnosa keperawatan, intervensi, implementasi dan evalusi tidak dilakukan oleh perawat. Pelaksanaan tindakan yang berhubungan dengan informasi sumbersumber pelayanan di masyarakat dan rujukan pasien kepada petugas kesehatan terdekat tidak dilakukan. Pelaksanaan discharge planning yang kurang optimal pada diagnosa, intervensi, implementasi dan evaluasi keperawatan oleh perawat di RSUD Prof. Dr. W.Z. Johannes Kupang disebabkan karena belum tersosialisasinya panduan discharge planning kepada seluruh pemberi pelayanan pasien, proses perubahan (revisi) panduan pelaksanaan discharge planning yang terlalu cepat (sudah 3 kali dalam 1 tahun), belum ada standar operasional prosedur (SOP) pelaksanaan discharge planning, dan persediaan format yang sangat terbatas.

3. Hubungan pengetahuan perawat dengan pelaksanaan discharge planning

Pengetahuan adalah segala informasi yang diperoleh secara terbiasa terhadap objek yang akan diingat oleh seseorang/kelompok tentang hal yang diketahui. Pengetahuan perawat diperoleh melalui pendidikan formal. Pengetahuan discharge planning yang umum harus diketahui diantaranya berupa pengetahuan tentang pengertian, tujuan, manfaat, prinsip, faktor risiko, prosedur discharge planning. Pengetahuan perawat tentang discharge planning diperlukan untuk mengkaji setiap pasien dengan mengumpulkan dan menggunakan data yang berhubungan untuk mengidentifikasi masalah aktual dan potensial, menentukan tujuan dengan atau bersama pasien dan keluarga, memberikan tindakan khusus untuk mengajarkan dan mengkaji secara individu 
dalam mempertahankan atau memulihkan kembali kondisi pasien secara optimal dan mengevaluasi kesinambungan Asuhan Keperawatan.

Penelitian ini membuktikan bahwa sebagian besar perawat di RSUD Prof. Dr. W.Z. Johannes Kupang memiliki pengetahuan baik sebesar 20 orang (50\%) dan perawat yang mempunyai pengetahuan baik yang melaksanakan discharge planning dengan baik sebanyak 6 orang (15\%). Hasil uji analisis korelasi koefisien spearman rank didapatkan kemaknaan $p=0,057>\alpha=0,05$ maka disimpulkan tidak ada hubung antara pengetahuan perawat dengan pelaksanaan discharge planning pasien di RSUD Prof. Dr. W.Z. Johannes Kupang. Hasil penelitian ini sejalan dengan penelitian yang dilakukan oleh Octaviani (2015) tentang Hubungan antara Pengetahuan perawat dengan pelaksanaan discharge planning di ruang rawat inap RS Dustira TK. II Cimahi diperoleh dari 25 perawat yang memiliki pengetahuan baik sebanyak $64.0 \%$ memiliki pelaksanaan baik, dan dari 40 perawat yang memiliki pengetahuan cukup sebanyak $35.0 \%$ memiliki pelaksanaan buruk. Hasil uji statistik didapatkan nilai $p$ value $=1.000>\mathrm{p}$ value ( $\mathrm{p}$ value $=0.05$ ) maka dapat disimpulkan tidak ada hubungan yang signifikan antara pengetahuan perawat dengan pelaksanaan discharge planning di ruang rawat inap RS Dustira Tk. II Cimahi.

Adapun faktor-faktor yang dapat mempengaruhi pelaksanaan discharge planning diantaranya adalah motivasi, supervisi pengawas, fasilitas, beban kerja, dan pengetahuan (Yulaita, 2011). Pengetahuan yang cukup tidak bisa menjamin perawat di RSUD Prof. Dr. W.Z.Johannes Kupang dapat memberikan discharge planning dengan baik, karena perawat mempunyai peran penting dalam pelaksanaan discharge planning pasien, dimana pelaksanaannya memerlukan pengetahuan yang baik sehingga apa yang disampaikan dapat dimengerti dan berguna untuk proses perawatan dirumah (Nursalam, 2009). Menurut Notoadmodjo (2007), pengetahuan dipengaruhi beberapa faktor yaitu pendidikan, umur, minat, pengalaman, kebudayaan, dan informasi. Salah satu faktor diatas yaitu pendidikan, umur, dan pengalaman mempunyai pengaruh besar terhadap pembentukan opini dan kepercayaan seseorang. Kecenderungan memiliki pengetahuan baik karena perawat di RSUD Prof. Dr. W.Z. Johannes Kupang mampu menjawab pertanyaan dengan benar tentang pengertian discharge planning, tujuan discharge 
planning, manfaat discharge planning, keberhasilan discharge planning, hal-hal yang harus diketahui pasien sebelum pulang.

Hasil penelitian ini menyimpulkan bahwa tidak ada hubungan antara pengetahuan perawat dengan pelaksanaan discharge planning di RSUD Prof. Dr. W.Z.Johannes Kupang. Pada umumnya perawat yang memiliki pengetahuan discharge planning yang baik tidak menjamin pelaksanaan discharge planning yang baik pula atau sebaliknya perawat yang memiliki pengetahuan kurang cendrung memiliki pelaksanaan discharge planning yang kurang. Hal tersebut menurut peneliti dikarenakan pengawasan yang kurang, mengacu pada fasilitas yang ada, dan dari sikap seseorang walaupun mempunyai pendidikan yang cukup akan tetapi jika ditunjang dengan pengalaman yang baik akan menumbuhkan pelaksanaan yang positif. Peneliti berpendapat bahwa tidak ada hubungan antara pengetahuan dan pelaksanaan discharge planning juga disebabkan karena tingkat pendidikan perawat yang dominan vokasional perawatan (D3 keperawatan). Notoadmojo (2007), menyatakan bahwa makin tinggi pendidikan seseorang semakin mudah pula mereka menerima informasi, dan pada akhirnya makin banyak pula pengetahuan yang dimilikinya.

4. Hubungan sikap perawat dengan pelaksanaan discharge planning

Sikap merupakan reaksi atau respon seseorang yang masih tertutup dari seseorang terhadap suatu stimulus atau obyek. Manifestasi sikap itu tidak dapat langsung dilihat tetapi hanya dapat menafsirkan terlebih dahulu dari perilaku yang tertutup, sikap secara nyata menunjukan konotasi adanya kesesuaian reaksi terhadap stimulus tertentu yang dalam kehidupan sehari-hari merupakan reaksi yang bersifat emosional terhadap stimulus sosial (Notoatmodjo, 2007).

Penelitian ini menunjukan bahwa sikap perawat dalam manajemen asuhan keperawatan tim di RSUD Prof. Dr. W. Z. Johannes Kupang, sebagian besar memperlihatkan sikap yang cukup baik. Perawat yang memiliki sikap cukup baik yang melaksanakan discharge planning dengan baik sebanyak 4 orang (10\%), sedangkan perawat yang memiliki sikap baik yang melaksanakan discharge planning dengan baik sebanyak 4 orang $(12,5)$. Hasil analisis statistik menunjukan bahwa ada hubungan yang bermakna antara sikap perawat dengan pelaksanaan discharge planning pasien dengan 
nilai signifikasi $(p)=0,00<\alpha=0,05$, maka dapat disimpulkan ada hubungan yang sedang antara sikap perawat dengan pelaksanaan discharge planning pasien.

Hasil penelitian di RSUD Prof. Dr. W.Z.Johannes Kupang menunjukan mayoritas sikap perawat cukup baik terhadap pelaksanaan discharge planning dan hanya sebagaian kecil memiliki sikap yang baik dalam pelaksanaan discharge planning. Hasil penelitian ini sejalan dengan penelitian oleh Wardani (2016) tentang hubungan tingkat pengetahuan dan sikap perwat dalam penanganan BBLR dengan asfiksis bahwa sikap perawat dalam penanganan bayi baru lahir dengan asfiksia di RSUD dr. Iskak Tulungagung menunjukan bahwa mayoritas perawat paling banyak mempunyai sikap yang positif sebesar $55 \%$ dan negatif sebesar $45 \%$ dengan nilai $p=0,025<\alpha=0.05$ menunjukan ada hubungan antara tingkat pengetahuan dan sikap dalam penanganan bayi baru lahir dengan asfiksia di RSUD dr. Iskak Tulungagung.

Azwar (2011), menyatakan bahwa pembentukan sikap dan faktor yang berpengaruh terhadap pembentukan sikap seorang ditentukan oleh pengalaman pribadi, pengaruh orang yang dianggap penting, pengaruh kebudayaan, pengaruh media massa, pengaruh lembaga pendidikan dan lembaga agama, pengaruh faktor emosional, dan pengaruh lingkungan. Media massa elektronik maupun media massa cetak sangat besar pengaruhnya terhadap opini dan kepercayaan seseorang. Dengan pemberian informasi melalui media massa mengenai sesuatu hal akan memberikan landasan kognitif baru terbentuknya sikap. Dalam hal ini penerbitan buku-buku tentang kedokteran maupun keperawatan dan jurnal-jurnal terkait dengan masalah kesehtan sangat berperan penting dalam pembentukan sikap terhadap pelaksanaan discharge planning di RSUD Prof. Dr. W. Z. Johannes Kupang. Notoatmodjo (2007), menyatakan bahwa perilaku seseorang atau masyarakat tentang kesehatan ditentukan oleh pengetahuan, sikap, kepercayaan dan tradisi sebagai faktor predisposisi disamping faktor pendukung seperti lingkungan fisik, prasarana dan faktor pendorong yaitu sikap dan perilaku petugas kesehatan atau petugas lainnya.

Hasil penelitian ini dapat disimpulkan bahwa sikap perawat terhadap pelaksanaan discharge planning dinyatakan cukup baik dimana hal ini disebabkan sikap yang dimiliki perawat merupakan respon batin yang timbul dan diperoleh berdasarkan pengetahuan sedangkan sikap perawat yang kurang baik disebabkan oleh predisposisi 
perilaku karena adanya beberapa orang yang kurang mendapat informasi atau tidak mengikuti sosialisasi dan bimbingan tentang discharge planning.

\section{KESIMPULAN}

1) Pengetahuan dan sikap perawat tentang discharge planning menunjukan bahwa sebagian besar perawat memiliki pengetahuan yang baik, dan sikap yang cukup baik.

2) Pelaksanaan discharge planning menunjukan bahwa perawat belum melaksanakan discharge planning secara tepat dan optimal.

3) Pengetahuan perawat mempunyai hubungan yang lemah dengan pelaksanaan discharge planning. (4) Sikap perawat mempunyai hubungan yang kuat dengan pelaksanaan discharge planning.

\section{DAFTAR PUSTAKA}

Arikunto, S. (2013). Prosedur Penelitian Suatu Pendekatan Praktik. Jakarta: Rineka Cipta.

Archie, R.R. \& Boren, S.A.. (2009). Opportunities for informatics to improve dischargebplanning: A systematic review of the literature. AMIA Annu Symp Proc.; 2009: 16-20. Published online 2009 November 14. PMCID: PMC2815402. http://www.amia.org/meetings/archives.asp. diperoleh tanggal 16 Nopember 2016

Azwar, Saifudin.(2011). Sikap manusia : teori dan pengukurannya edisi 2. Yogyakarta : Pustaka pelajar.

Blais, K.K., Hayes, J.S., Kozier, B., \& Erb, G. (2007). Praktik keperawatan professional: konsep \& perspektif (edisi 4). Jakarta: EGC.

Birmingham, J. (2010). Discharge planning guide tool for compliance. Third edition. United Sates of America: HCPro. Inc.

Carpenito, L.J. (2009). Nursing care plans \& documentation: Nursing diagnosis and collaborative problems. 5th edition. Philadelphia: Wolter Kluwer Health. Lippincott William \& Wilkins.

Cherlin, E., Curry, L., Krumholz, H., \& Bradley, E. (2012). Features of high quality discharge planning for patients following acute myocardial infarction. Journal general internal medicine. 28(3):436-443. Doi:10.1007/s11.606-012-2234-y.

CMS. (2008). Planning for your discharge: A checklist for patients and caregivers preparing to leave a hospital, nursing home, or other health care setting.

Dessler, G. (2009). Manajemen sumber daya manusia. Jilid 2. Alih bahasa Paramita Rahayu. Editor Fadjar Hari Hardiansjah. Edisi ke-10. Jakarta : PT. Indeks.

Fraenkel, J.R dan Wellen, N.E. 2008. How to Design and Evaluate research in Education. New York: McGraw-Hill. 
Hariyati, R.T.S., Afifah, E., \& Handiyani, H. (2008). Evaluasi model perencanaan pulang yang berbasis teknologi informasi. Makara, Kesehatan. Volume 12. No.2. Desember 2008

Huber, D.L. (2010). Leadership \& nursing care management (4 ed.). Missouri: Saunders Elsevier.

Ilyas, YY. (2011). Perencanaan sumber daya manusia rumah sakit: teori, metode \& formula (edisi 1). Jakarta: FKM UI.

Kleinpell, R.M. (2004). Randomized trial of an intensive care unit - based early discharge planning intervention for critically ill elderly patients. American Journal of Critical Care. 2004;13:335-345. July 2004, Volume 13, No. 4.

Marquis, B.L., \& Huston C.J. (2012). Leadership roles \& management functions in nursing: Theory and application (7 ed). California: Lippincott Williams \& Wilkins.

NANDA International. (2015). Diagnosis Keperawatan: defenisi \& klasifikasi 2015 - 2017; Editor Herdman, T.H, Kamitsuru, S. ; alih bahasa, Keliat, B.A. Ed. 10. Jakarta: EGC

NCSS. (2006). Care and discharge planning: A guide for service providers. Serial No: 032/SDD19/DEC06. Singapore: National Council of Social Service.

Nosbusch, J.M., Weiss, M.E., \& Bobay, K. L. (2011). An integrated review of the literature on challenges confronting the acute care staff nurse in discharge planning. Journal of Clinical Nursing. Publisher: Wiley-Blackwell. Volume 20, Numbers 5-6, March 2011 , pp. 754-774(21)

Notoatmodjo. (2007). Metodelogi Penelitian Kesehatan. Jakarta : Rineka Cipta

Notoatmodjo. (2009). Metodelogi Penelitian Kesehatan. Jakarta : Rineka Cipta

Nursalam. (2013). Metodologi Penelitian Ilmu Keperawatan: Pendekatan Praktis. Edisi tiga. Jakarta: Salemba Medika.

Nursalam. (2013). Manajemen keperawatan: aplikasi dalam praktik keperawatan professional (edisi pertama). Jakarta: Salemba Medika.

Octaviani K.R., \& Darmawan D., (2015). Hubungan antara pengetahuan perawat dengan pelaksanaan discharge planning di ruang rawat inap rumah sakit tk. II Dustira Cimahi. Jurnal Keperawatan Aisyiya, vol. 2. (ISSN 2355-6773)

Owyoung, P. (2010). Role of a nurse in discharge planning. (April 21, 2010, http://www.ehow.com/about_6367124_role-nurse-discharge-planning.html \#ixzz1H14p8zop, diperoleh tanggal 11 Nopember 2016)

Poglitsch, L.A., Emery, M., \& Darragh, A. (2011). A qualitative study of the determinants of successful discharge for older adult inpatients. Journal of American Physical Therapy Association. (ISSN 1538-6724)

Pemila, U. (2009). Konsep discharge planning. http://www.fik.ui.ac.id/pkko/files/ KONSEP\%20DISCHARGE\%20PLANNING.doc., diperoleh tanggal 11 September 2016)

Potter, P.A. \& Perry, A.G. (2005). Buku ajar fundamental keperawatan: Konsep, proses dan praktik. Volume 1. Alih bahasa Yasmin Asih, et al. Editor edisi bahasa Indonesia Devi Yulianti, Monica Ester. Edisi 4. Jakarta: EGC.

Robbins, S.P. (2006). Perilaku organisasi. Edisi kesepuluh. Jakarta: PT. Indeks Kelompok Gramedia.

Rofi, M. (2011). Analisis faktor-faktor yang mempengaruhi Pelaksanaan perencanaan pulang pada Perawat di rumah sakit islam Sultan agung semarang. Tesis. Jakarta: FIK UI. Tidak dipublikasikan. 
Rofi'i., Hariyati., \& Pujasari. (2012). Perjanjian dan konsensus dalam pelaksanaan perencanaan pulang pada perawat di rumah sakit. Jurnal Keperawatan Indonesia. Volume 15 (3), 207-214. http://jki.ui.ac.id.

Siagian, S.P. (2006). Teori dan praktek kepemimpinan.Cetakan kelima. Jakarta: PT Rineka Cipta.

Sugiyono. (2011). Metode penelitian kuantitatif, kualitatif dan $R \& D$. Cetakan ke-12. Bandung: Alfabeta.

Sugiyono.( 2013). Metode Penelitian Kuantitatif Kualitatif dan $R \&$ D . Bandung : Alfabeta.

Sulistiyawati W., (2015). Implementasi Fungsi Manajemen Dalam Pelaksanaan Discharge Planning. Jurnal ilmiah keperawatan, vol. 10, http://www.stikeshangtuah-sby.ac.id

Sulistiyawati W., Hariyati S.R., \& Kuntarti (2016). Implementasi Sistem Jenjang Karir Dalam Pelaksanaan Discharge Planning. Jurnal Ilmu Keperawatan, vol.4

Swansburg, R.C. (2000). Pengantar kepemimpinan dan manajemen keperawatan. Alih bahasa Suharyati Samba. Editor Monica Ester. Jakarta: EGC.

Swansburg, R.C., \& Swansburg, L.C.. (2002). Pengembangan staf keperawatan: suatu komponen pengembangan sumber daya manusia. Alih bahasa Agung Waluyo, Yasmin Asih. Editor Monica Ester. Jakarta: EGC.

Terry, G.R., \& Rue, L.W. ((2010). Principles of management. Illionis: Homewood

Tomey, A.M. (2009). Guide to nursing management \& leadership (8 ed.). Missouri: Mosby Elsevier.

Wardani, M.K., Isnaeni E., \& Andy Y. (2015). Hubungan Tingkat Pengetahuan Dan Sikap Perawat Dalam Penanganan Bayi Baru Lahir Dengan Asfiksia di RSUD dr. Iskak Tulungagung, Jurnal ilmiah keperawatan, vol. 10, http://www.stikeshangtuahsby.ac.id

Wahyuni., Nurachmah, E., \& Gayatri. (2012). Kesiapan pulang pasien penyakit jantung koroner melalui penerapan discharge planning. Jurnal Keperawatan Indonesia. Vol 15(3):151-58. http://jki.ui.ac.id/index.php/jki/article/view/3 